\title{
COMPONENTS, CRITERIA AND INDICATORS OF PSYCHOLOGICAL READINESS OF TANK UNITS SOLDIERS
}

\author{
Olga Yurkova \\ Postgraduate Student at the Department of Moral and Psychological Support of the Activity \\ of the Troops (Forces), National Defence University of Ukraine \\ named after Ivan Cherniakhovskyi, Ukraine \\ e-mail: yrkova.ya@gmail.com,orcid.org/0000-0002-5679-6584
}

\section{Summary}

The article deals with an empirical study of the components and theoretical substantiation of indicators and criteria of psychological readiness of tank units soldiers to execute combat tasks and missions.

It is determined that the psychological readiness of a tanker is an independent, multifunctional psychological formation, which has a stable positive correlation with the effectiveness to execute a mission; consists of a number of components that interact with each other; is shaped in the process of undergoing a professional training course by a soldier.

Applying the method of expert assessments, we have identified and scientifically substantiated that psychological readiness consists of motivational, emotional-volitional, personal and functional components. They were ranked according to their significance. The content of these components is disclosed in criteria that are identical in name. In turn, the criteria are shaped from a number of indicators that reflect the psychological, emotional, and cognitive specificity of the psychological readiness of tank units.

Substantiated indicators and criteria allowed us to choose a psychodiagnostic tool for a comprehensive study of the phenomenon of psychological readiness of soldiers of tank units to perform combat missions. Given the complexity of the subject of research, the requirement for psychodiagnostic tools is the partial overlap and complementarity of one method to another and the possibility of their use without separation of the subjects from military service.

Keywords: psychological readiness, tank unit, components, indicators, criteria, research methodology.

DOI: https://doi.org/10.23856/4918

\section{Introduction}

Modern Ukraine is going through a difficult and responsible stage of its development, which is caused by the increase in crisis phenomena, the emergence of new threats and challenges to national security, in particular in the military domain (Chornyi, 2019: 179). This is particularly relevant in the context of the growing military confrontation with the Russian Federation, which has amassed significant military groups around our borders, including armored ones.

In such conditions, the fundamental factor in the effectiveness and reliability of performing combat tasks by military personnel of tank units is a developed psychological readiness to act in any conditions. 


\section{Problem statement}

In modern psychological science, there is a steady tendency to increase the number of research ${ }_{2}$ devoted to various aspects of psychological readiness of military personnel of different branches of the armed forces, but, along with this, it is obvious that the issue of psychological readiness of tank units soldiers is not sufficiently studied at a time when tankers have one of the key positions in the defense capability of the Ukrainian Armed Forces. After all, they participate in defensive and offensive actions and build the basis of combined-arms combat.

The task execution by tank units is often accompanied by significant psychoemotional and physical stress of their personnel and pose an immediate threat to the life and health of each crew. Hence, there is a need to shape the psychological readiness of tank units soldiers to perform combat tasks.

Substantiation of components, criteria and indicators of psychological readiness of tank units soldiers will allow to confirm or refute the effectiveness of the system of psychological training at the level of professional training. Also, determining the level of psychological readiness will allow to adjust and optimize the process of psychological training, influence the building of professional qualities of tankers, in other words, to train a reliable professional in accordance with the requirements of modern combat operations.

So, the purpose of this paper is the definition and substantiation of components, criteria and indicators of the level of development of psychological readiness of tank units soldiers during the combat tasks execution. At the same time, our article is not limited to defining the components, criteria and indicators of psychological readiness of tank units soldiers, but also outlines ways to improve them.

\section{Main features of soldiers' psychological readiness}

In the scientific literature, functional, personal and personality-activity approaches in order to define the concept of psychological readiness for activity are generally considered. Depending on the approach to the interpretation of this concept, the authors define its different structure, main components and methods of establishment.

As a result of our theoretical analysis of scientific achievements, it becomes clear that psychological readiness is a system of psychological and psychophysiological characteristics of an object that ensure the success and effectiveness of certain actions and activities. Therefore, it is impossible to study the problem of readiness for professional activity without studying its components, criteria and indicators.

Psychological readiness of soldiers of tank troops is a necessary condition for effective actions in a combat situation, which makes it possible to manage their mental state and make informed decisions in non-standard situations. It has the properties of a general readiness of the individual for activities, but with the presence of specifics that are characteristic only for representatives of tank units.

\section{Research methodology of psychological readiness of tank units soldiers}

The methodological basis of our research is the principles of system and activity approaches. A feature of the professional activity of military personnel of tank units is known to be the inclusion of tank crew members in two systems of interaction: "man - man" and "manvehicle", which gives grounds to consider this issue in the plane of a systematic approach. 
Nevertheless, a significant aspect is that a tanker is an object of individual and collective activity. Being in a professional environment, a soldiers learns, develops and shows his professional skills, which we interpret as a prerequisite for studying the outlined issue from the point of view of activity-based approach.

In our opinion, this situation does not cause any contradictions, and the involvement of two scientific approaches to understanding the psychological readiness of tank units soldiers does not level each other, but only enhances the purity of each other's research. Such a collaboration will allow us to study the theoretical and practical aspects of the psychological readiness of tankers, as a holistic process, it is aimed at improving the effectiveness of professional activities and maintaining psychological health before, during and after combat mission execution.

To achieve this aim, general scientific and specific research methods were used in the preparation of the article.

\section{Current state of development of psychological readiness of tankers}

Unfortunately, nowadays there are no scientific papers devoted to the study of psychological readiness of tank units soldiers, so defining the components, we took into account the scientific views of scientists who studied the professional activities of military personnel of other branches of the Armed Forces, namely: Ahaieva N., Anokhina P., Dobrianskyi O., Yermakova I., Kokun O., Korolchuk M. , Lebedieva V., Maksymenko S., Molotaia V., Mula S., Penkova N., Puni A., Smirnova A., Timchenko O., Uznadze D., Yahupova V.

The problem of the lack of methods responsible for the principles of psychodiagnostics in determining the components of psychological readiness of tank units soldiers has led to the need for a special study. This study was carried out using the method of expert assessments.

37 respondents took part in the expert survey. The experts were command-level officers with experience of serving in tank units from 8 to 22 years, aged from 27 to 43 years. All experts had experience in performing combat tasks in the JFO (ATO). Based on the results of the survey, four components of psychological readiness of tank units soldiers were identified (fig. 1) which contained 16 characteristics of psychological readiness to perform a combat mission (table. 1).

Let's focus on the characteristics of the components of psychological readiness of tank units solduers (Yurkova, 2021: 209).

Motivational component. The dominant role of the motivational component is to drive (include) such components. The nature of this component has a close connection with an emergence of certain needs and motives for their satisfaction. The outcome of the motivational component work is the establishing a new goal, the desire to be a role model, taking the desired place in the career hierarchy, the manifestation of professional abilities to update own professional identity.

Emotional and volitional component. This component allows to withstand all the adversities of combat clashes, understand the consequences of professional activity, accept possible difficulties and outline ways to overcome them, determine a goal and make decisions independently, adequately assess the situation with further focus on a priority task. Volitional efforts are made in conditions of strong moral and emotional-psychological tension. That is why the volitional component is one of the main root causes of the development of psychological readiness of a tank unit.

Personal component. It is characterized by adequate professional self-esteem, acceptance of the rules and requirements of the military community, respect for the personal space of other people in the team, and so on. Another of the main determinants of the personal component is an 
interest in the profession, which correlates with the needs for development and recognition in both the personal, professional, and public fields. The personal component mandatory includes the object having the necessary level of intellectual and physical development.

Functional component transfers the resources available to a soldier necessary for performing professional activities:

- physical - development to the highest level of automatism of sensorimotor, semantic and ideomotor processes;

- mental - knowledge, skills and abilities, intellectual capabilities, which in agreement with each other, build the basis of professional skill of tank crewmen.

Table 1

\section{Characteristics of the components of psychological readiness of tank units soldiers}

\begin{tabular}{|c|c|c|c|}
\hline Component & Percentage & Individual psychological characteristics & Percentage \\
\hline \multirow{4}{*}{$\begin{array}{l}\text { Motivational } \\
\text { component }\end{array}$} & \multirow[t]{4}{*}{$97 \%$} & Interest in the profession and its values & $90 \%$ \\
\hline & & Motivational focus on self-development & $85 \%$ \\
\hline & & $\begin{array}{l}\text { Motivational focus to identify yourself } \\
\text { as a professional }\end{array}$ & $85 \%$ \\
\hline & & $\begin{array}{l}\text { Motivation to get the desired status } \\
\text { and influence }\end{array}$ & $82 \%$ \\
\hline \multirow[t]{4}{*}{$\begin{array}{l}\text { Emotional- } \\
\text { volitional } \\
\text { component }\end{array}$} & \multirow[t]{4}{*}{$93 \%$} & $\begin{array}{l}\text { Ability to adequately perceive the specifics } \\
\text { of military service (regulated life, daily rou- } \\
\text { tine, unity of command) }\end{array}$ & $84 \%$ \\
\hline & & $\begin{array}{l}\text { Ability to take responsibility and make } \\
\text { decisions in extreme operating conditions }\end{array}$ & $84 \%$ \\
\hline & & $\begin{array}{l}\text { Ability to control yourself in critical } \\
\text { situations (stress tolerance, resistance) }\end{array}$ & $84 \%$ \\
\hline & & $\begin{array}{l}\text { Ability to take joint, decisive, } \\
\text { proactive actions }\end{array}$ & $83 \%$ \\
\hline \multirow{4}{*}{$\begin{array}{l}\text { Personal } \\
\text { component }\end{array}$} & \multirow[t]{4}{*}{$80 \%$} & Sense of military duty and patriotism & $90 \%$ \\
\hline & & $\begin{array}{l}\text { Awareness of the importance } \\
\text { of professional activity }\end{array}$ & $88 \%$ \\
\hline & & $\begin{array}{l}\text { Ability to organize joint activities } \\
\text { and monitor their outcomes }\end{array}$ & $87 \%$ \\
\hline & & Sociability, teamwork & $86 \%$ \\
\hline \multirow[t]{4}{*}{$\begin{array}{l}\text { Functional } \\
\text { component }\end{array}$} & \multirow[t]{4}{*}{$77 \%$} & $\begin{array}{l}\text { Ability to think spatially (ability to display } \\
\text { spatial and temporal-spatial properties } \\
\text { and relationships in the environment) }\end{array}$ & $82 \%$ \\
\hline & & $\begin{array}{l}\text { Ability to work effectively } \\
\text { in a confined space }\end{array}$ & $79 \%$ \\
\hline & & Physical development/endurance & $79 \%$ \\
\hline & & $\begin{array}{l}\text { Ability to maintain high activity } \\
\text { for a long time }\end{array}$ & $78 \%$ \\
\hline
\end{tabular}




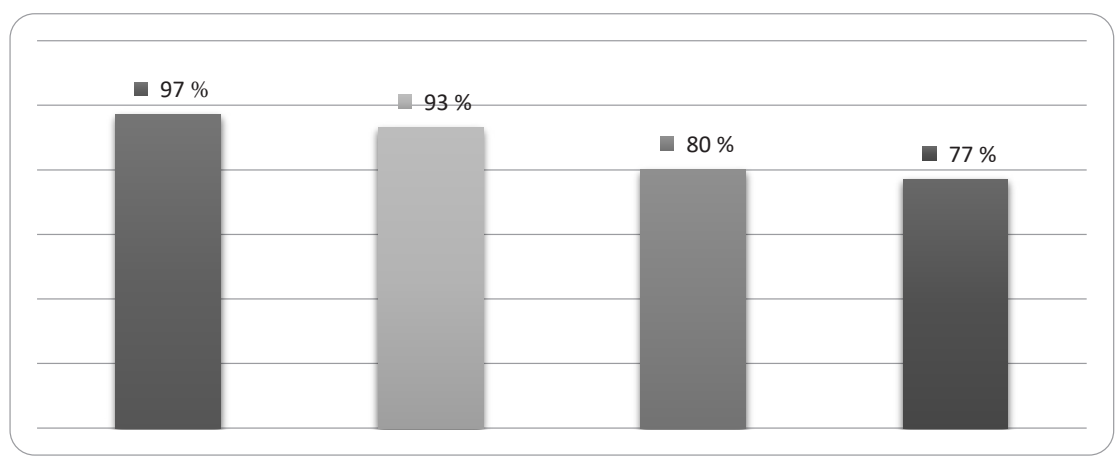

\section{Fig. 1. Results of ranking components of psychological readiness of tank units soldiers}

The functional component has the greatest applied value: the ability to calculate the resource of one's own forces in relation to the forces and resources of an enemy, knowing tactical methods of combat, physical endurance (long stay in a confined space, long work in conditions of intense combat operations and during monotonous periods of activity (for example, in the case of redeployment).

Based on the above-mentioned information, one needs to clarify a number of basic concepts such as "criterion" and "indicator" in order to fully achieve stated aim. Psychological literature has many definitions of the concept of "criterion", but most often, a criterion is a feature by which mental phenomena, actions or activities are classified, evaluated (and get an assessment) by the corresponding indicator, in particular, during their formalization (Bodrovskyi, 2007: 164). An indicator is understood as evidence, proof, sign of something; data on the outcomes of any work or activity (Kusayikina N., Tsybulnyk Yu., 2011: 528)

According to E. Potapchuk, who studied the psychological readiness of border guards, defined indicators and criteria allow to track exactly those characteristics that are responsible for the success of professional activity and help climb career ladder (Potanchuk, 2013: 77).

In the scientific papers, S. Maksymenko notes that the established criteria for psychological readiness of a soldier for combat operations indicate the effectiveness of psychological readiness as the degree of compliance of the outcomes of this activity with certain goals and regulatory requirements (Maksymenko, 2002: 478).

Studying the psychological readiness of young officers for service and combat activities, Storozhuk N. identifies two integral criteria of psychological readiness, namely: external (to which she refers the effectiveness of performing service and combat tasks) and internal (which is revealed in the moral and psychological state). We agree with the author's opinion that there is a stable relationship between indicators and criteria that represent a correlation galaxy the level of psychological readiness (Storozhuk, 2010: 61).

Thus, the outlined psychological characteristics of criteria and indicators of psychological readiness of tankers were determined on the basis of an analysis of scientific papers devoted to $_{2}$ this issue and the method of expert assessments. In our case, the components of psychological readiness of tank units soldiers are the basis of criteria, namely: the motivational component meets the motivational criterion of motivation; the emotional-volitional component meets the emotional-volitional criterion; the personal component meets the personal criterion; the functional component meets the criterion of functionality, and the detailed content of the criteria represents their indicators. 
So, summing up all the accumulated papers, we determined the following indicators and the corresponding criteria for psychological readiness of tank unit soldiers to execute combat tasks and missions.

Thus, the following indicators correspond to the motivational criterion of psychological readiness of a tanker:

- awareness of the social importance of own activities;

- striving for self-development in the profession;

- interest in the values of the profession;

- determination to achieve success in the profession;

Taking into account the characteristics that experienced tankers have, indicators of the emotional and volitional criterion are the following:

- ability to make decisions in extreme combat conditions;

- realistic assessment of the situation developed during the battle;

- perseverance in overcoming trials and tribulations of military service;

- risk preparedness in dangerous circumstances;

- systematic psychoemotional stability;

- self-control of the psychoemotional state;

- ability to act in new, unknown circumstances;

- frustrating tolerance;

In accordance with the requirements of personal qualities as components of psychological readiness, the following indicators meet the above-mentioned criterion:

- effective activity in subordination;

- willingness to resolve conflicts in a crew;

- coordinated responses to circumstances and target designations;

- internal control of own behavior during actions;

- ability to restore the psychoemotional state in a short time (resiliency);

- professional activity;

Today, the following indicators meet the functional criterion:

- teamwork ability;

- consistency of the sequence of actions in a crew;

- interest in professional cooperation;

- ability to analyze, assess and predict possible course of actions;

- ability to keep your attention on several things at the same time for a long time;

- ability to swiftly switch attention from one thing to another one;

- distribution of attention between important things;

The specific content of the components, criteria and their indicators allowed us to determine the main directions of research on the development of psychological readiness of tank units soldiers. Taking into account the fact that today there is no single tool for studying this phenomenon, we have applied such psychodiagnostic methods that partially overlap and complement each other and can be applied without interrupting the subjects from military service. So, we have chosen the diagnosing professional motivation method (Osodlo V. I.), diagnosing group motivation method (Ladanov I. V.), R. Kettell’s personal questionnaire. Кеттелла (№105), шкалутривожностіТейлора в адаптації M. Peisakhov, the method of diagnostics of the volitional potential of the individual (Fetiskin N. P.), the method of assessing the psychological atmosphere in the team (Fidler A. F. in the adaptation of Khanin Yu. L.), the numerical series technique, the Pieron-Ruzer technique .

The main criteria on the basis of which the methods were selected were (Korolchuk, 2009: 15) sufficient information content (validity), reliability (stability), accuracy, practicality of the results obtained, relevance. Compliance with these requirements at all stages of the experiment will ensure high information content and reliability of the results obtained, which in the future will become the basis for making reasonable conclusions. 


\section{Conclusions}

The analysis of scientific papers, an expert survey and experience of service in tank units allowed us to draw the following conclusions:

1. Based on the above-mentioned information, we have outlined four components of psychological readiness of tank unit soldiers to execute combat tasks and missions, namely: motivational, emotional-volitional, personal and functional.

2. Based on the substantiated components and their individual psychological characteristics, indicators and criteria for assessing the levels of development of psychological readiness were formulated.

3. Taking into account the specifics of professional activity and the described indicators and criteria, we have selected a group of psychodiagnostic methods and techniques that meet certain criteria and indicators of our research.

Research of the level of development of psychological readiness of of tank units soldiers to execute combat missions and tasks are prospects for further research.

\section{References}

Brodovska V. Y., Hrushevskyi V. O., Patryk I. P.B (2007) Tlumachnyi rosiisko-ukrainskyi slovnyk psykholohichnykh terminiv [Explanatory Russian-Ukrainian dictionary of psychological terms]: Slovnyk. Kyiv: VD «Profesional», 512.

Korolchuk M. S. (2009) Psykhofiziolohiia diialnosti [Psychophysiology of activity]. Pidruchnyk dlia studentiv vyshchykh navchalnykh zakladiv. Kyiev. Elha, Nika-Tsentr, 400 s. [in Ukrainian] Kusaikina N. D. Tsybulnyk Yu. (2011) Suchasnyi tlumachnyi slovnyk ukrainskoi movy [Modern explanatory dictionary of the Ukrainian language]. zah. red. d-ra filol. nauk, prof. $V$. V. Dubinynskoho. Xarkiv: VD «ShKOLA». [in Ukrainian]

Maksymenko S. D. (2002) Osnovy viiskovoi psykholohii [Fundamentals of military psychology]: navchalnyi posibnyk/S. D. Maksymenko, P. V. Melnyk, B. M. Oleksiienko. Khmelnytskyi : NAPVU. [in Ukrainian]

Potapchuk Ye.M. (2013) Kryterii, pokaznyky ta rivni psykholohichnoi hotovnosti personalu prykordonnykh pidrozdiliv do dii v ekstremalnykh umovakh [Criteria, indicators and levels of psychological readiness of border guards to act in extreme conditions]. Naukovyi chasopys Natsionalnoho pedahohichnoho universytetu imeni M. P. Drahomanova. № 41 (65), S. 71-78. [in Ukrainian]

Storozhuk N.A. Formuvannia psykholohichnoi hotovnosti molodoho ofitsera Zbroinykh Syl Ukrainy do sluzhbovo-boiovoi diialnosti [Formation of psychological readiness of a young officer of the Armed Forces of Ukraine for military service]: dys. . kand. . psykh. nauk: 19.00.09/ Storozhuk Nataliia Andriivna. Kyiv. 150 s. [in Ukrainian]

Chornyi V. S. (2019) Ukrainske suspilstvo na suchasnomu etapi: vyklyky i zahrozy [Ukrainian society at the present stage: challenges and threats]. Sotsiolohiia: teoriia, metody, marketynh. 2019. № 3 (lypen - veresen). S. 179-194. [in Ukrainian]

Yurkova O. I. (2021) Strukturno-funktsionalna model rozvytku psykholohichnoi hotovnosti viiskovosluzhbovtsiv tankovykh pidrozdiliv do vykonannia boiovykh zavdan [Structural and functional model of development of psychological readiness of servicemen of tank units to perform combat missions]. Polish Scientific Journal KELM (Knowledge, Education, Law, Management), № 1 (37), vol. 2. S. 206-214[in Ukrainian] 